\title{
Research of Biomass Micro-Cogeneration System Integration With a Solar PV Panels in Zero-Energy Family Building
}

\author{
Jānis Kramens \\ Institute of Energy systems and \\ Environment, Riga Technical \\ university \\ Riga, Latvia \\ digiteks.info@gmail.com
}

Viktorija Terjanika

Institute of Energy systems and

Environment, Riga Technical

university

Riga, Latvia

viktorija.terjanika@rtu.lv

\author{
Edgars Vīgants \\ Institute of Energy systems and \\ Environment, Riga Technical \\ university \\ Riga, Latvia \\ edgars.vigants@rtu.lv
}

\author{
Ivars Liepiņ̌s \\ Institute of Energy systems and \\ Environment, Riga Technical \\ university \\ Riga, Latvia \\ ivars.liepins@komforts.lv
}

\begin{abstract}
Nowadays, any economic development is based on its sustainability. On the other hand, sustainability of the economy is no longer conceivable without efficient use of resources. Climate change and environmental degradation affects everybody and have no borders. It is essential, that all countries, regardless of their existing resources, are involved in environmental matters. The European Union (EU) has taken the initiative and has seen the possibility of transforming climate change into a guiding theme for sustainability and development in the economy. The EU has developed a green policy in order to transform all economic sectors into sustainable use of resources. EU is planning to achieve climate neutralisation in all sectors of the economy by year 2050. In order to achieve this objective, only the transformation of the industrial, transport and energy sectors will not be sufficient. The activity and willingness of each individual to achieve these objectives at their own

Keywords - Efficiency, environmental impact, microcogeneration, off-grid, sustainability
\end{abstract}

\section{INTRODUCTION}

If we look at the structure of Latvian households and their potential to use biomass micro cogeneration (mCHP) equipment for heat and electricity production in combination with solar panels for self-consumption, we must first assess the number of households that could use household level will be crucial. It should change habits in all sectors important for households: food, transport, waste management and decreasing energy consumption in all mentioned sectors. Solar PV panels traditionally are used to reach zero balance, but taking in to account climatic conditions and seasonable solar irradiation activity, they can operate successfully during the summer and partly during the spring and autumn season. During the heating season, the efficiency of solar PV panel systems is very low. Use of innovative micro-cogeneration equipment producing both heat and electricity is more efficient during heating season in Latvia.

In this paper case study of innovative biomass Stirling engine micro-cogeneration system integration with a solar PV panels in zero-energy family building will be present.

this type of equipment. As with high-capacity biomass cogeneration (CHP), in the case of $\mathrm{mCHP}$, the primary factor for its efficient operation is the efficient and effective use of heat, in the case of households it will be heat for heating and hot water for domestic use. If we compare the amount of heat consumed for heating and hot water

\section{Online ISSN 2256-070X


preparation, then on an annual basis heating requires on average twenty times more heat, so the data obtained during the heating season should be used for mCHP calculations. In turn, the solar panel system must be viewed from the structure of household electricity consumption. Household electricity consumption also varies with the time of year and the season, but the change in consumption in this case is not so much related to the start of the heating season as to the decrease in daylight hours in winter and the increase in electricity consumption for lighting. On average, these fluctuations in household electricity consumption between winter and summer season do not fluctuate by more than $50 \%$. This seasonal fluctuation in electricity consumption is the opposite of the fluctuation in solar panel production, which is several times higher in the summer season than in the winter season. At present, combined heat and power solutions are not popular in the household sector, and while such fossil fuel based mCHP solutions are still available, solutions based on biomass fuels are rare and not widespread. It is generally accepted that the most successful solution for households to achieve Zero Climate Balance (NET) is the installation of solar panels. According to the authors, such a theory is also closely related to the development of solar panel technology, because until recently it was considered that solar panels can be successfully used only in southern countries such as Italy and Spain, where in households electricity is as primal energy type and thermal energy - as secondary. With the development of solar panel technology, their efficiency indicators improved, and accordingly it became economically justified to use solar panels in Northern European countries, where heat consumption is the primary energy balance in households. Accordingly, in regions where heat consumption is significant or even higher than household electricity consumption, it is not appropriate to compensate for this increase in energy consumption with a larger area of solar panels. The northern regions also have more pronounced changes in solar intensity during the winter and summer, so in order to cover the increase in household energy consumption, the area of solar panels needs to be increased several times, which creates a significant surplus of energy in the summer and additional load on energy supply grid. In Northern European countries, including Latvia, forest areas are on average twice as large as the European average, therefore it would be useful to compensate with this renewable energy sources (RES) the increase in the consumption of seasonal energy resources (wood). Seasonal changes in the consumption of these householdcritical resources, climatic conditions and the availability of RES provide good evidence for the usefulness of the study presented in this article.

There are 817900 households in Latvia (in 2019), of which more than $56.4 \%$ are connected to the district heating (DH), but the rest (356 600) are provided with individual heat supply equipment - wood, pellet, gas or other resource heating boilers, various types of heat pumps and heating using electricity from the grid [1]

The majority (60 \%) of households that provide individual heat supply are located in rural areas. If the most optimal development scenario for a household with individual heat supply in an urban area would be connection to the District heating (DH) in the future, then in rural areas, in most cases, such option will not be economically justified. Assuming a scenario that in the future these households in rural areas with individual heat supply, which is 212429 units, or $26 \%$ of all Latvian households [2], will use efficient heat production equipment together with mCHP and solar panels, this will have a significant effect on achieving Latvia's Green Deal goals, promoting the country's energy independence and efficient use of local renewable energy resources. Households are one of the largest and most inefficient consumers of energy resources in the country, as well as one of the largest emitters, so any effective solution to achieve these goals is essential for achieving climate goals. biomass heating system with integrated mCHP Stirling engine in combination with a solar panels would be the most effective solution taking into account the geographical position of Latvia and the availability of biomass (wood) resources in rural areas.

Objectives of the research:

- Household Electricity Calculation (NET) system solution with a smooth production and consumption curve.

- Achieving $\mathrm{CO}_{2}$ neutrality in the supply of heat and electricity to households

\section{SYSTEM DESCRIPTION}

\section{A. System Components}

As mentioned in the introduction, the system for investigation consists of a micro-cogeneration unit based on external combustion Stirling engine and a solid biomass gasification boiler and a solar photovoltage panels (PV).

\section{B. mCHP System}

A prototype of a solid biomass micro-cogeneration unit was used for the experiments. An " $A$ " class solid biomass heating boiler Magasro $31 \mathrm{~kW}$ [3] was used to create the prototype. This boiler was chosen due to the latest available technologies in the field of household biomass boilers. According to the Stirling engine performance [4], the boiler must be able to heat the engine head to at least $550{ }^{\circ} \mathrm{C}$ in order to achieve maximum Stirling engine efficiency. This head temperature can be ensured by the combustion of the gas obtained from the wood gasification process of the used boiler in the combustion chamber (Fig. 1). 
Environment. Technology. Resources. Rezekne, Latvia Proceedings of the $13^{\text {th }}$ International Scientific and Practical Conference. Volume 1, 132-138

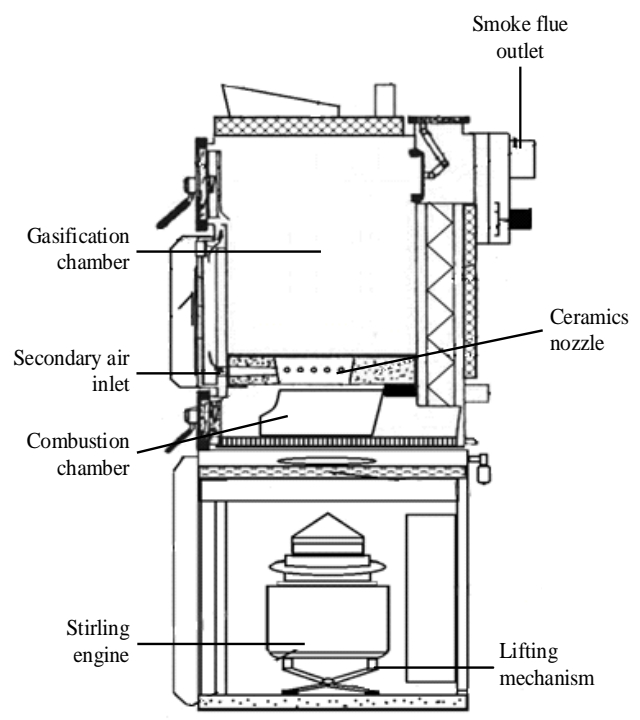

Fig. 1. Schematic representation of the experimental equipment with the lifting mechanism.

\section{Solar PV System}

For the research, a solar PV panel system was created on the roof of the building $14^{\circ}$ in relation to the horizon with a south-facing position, the installed total panel power is $1200 \mathrm{~W}$, Fig. 2.

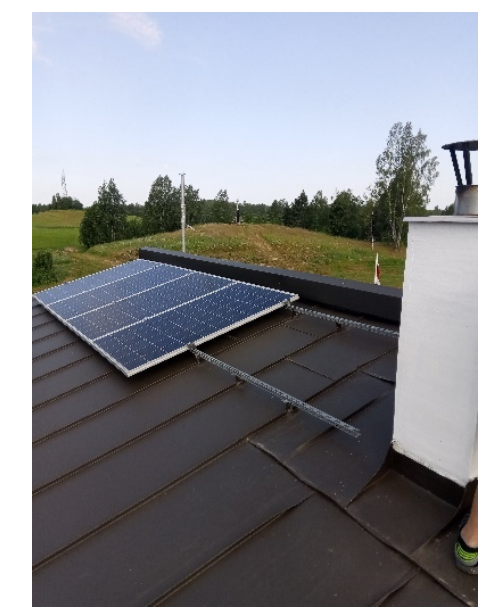

Fig. 2. experimental PV solar panel system.

Stirling engine micro-CHP equipment parameters are shown in Table 1.

TABLE 1. MCHP SYSTEM DESCRIPTION

\begin{tabular}{|l|l|}
\hline \multicolumn{2}{|c|}{ mCHP system description } \\
\hline engine model & Microgen $1.0 \mathrm{~kW}$ \\
\hline engine type & external combustion \\
\hline engine alternator electrical power & $1.0 \mathrm{~kW}$ \\
\hline cooling type & fluid \\
\hline boiler model & Magasro 30 \\
\hline boler type & solid biomass gasification \\
\hline boiler heating power & $31 \mathrm{~kW}$ \\
\hline
\end{tabular}

TABLE 2. PV SYSTEM DESCRIPTION

\begin{tabular}{|l|l|}
\hline \multicolumn{2}{|c|}{ PV system description } \\
\hline number of panels & 4 \\
\hline panel electrical power & $300 \mathrm{~W}$ \\
\hline panel model & Canadian Solar \\
\hline Inverter & Solar Inverter (Bimle solar) \\
\hline
\end{tabular}

III. MATERIALS

\section{A. Household Loads and System Description}

The system runs continuously, following typical electrical and thermal demand profiles in households. The installation is able to apply real thermal and electrical loads according to set demand profiles. Data of the main operating parameters of the system is collected on tests that run without errors for $24 \mathrm{~h}$ (whole days). The monitored variables include meteorological conditions (radiation, temperature, humidity, etc.), electrical production and consumption, water temperatures and flow rate in all the water circuits and the Stirling engine system variables. To evaluate the system, the main results from each day are further analysed, according to the methodology described below.

\section{B. Household Thermal Loads}

According to Latvian construction standards, the heat energy consumption of residential houses is allowed up to $90 \mathrm{kWh} / \mathrm{m}^{2}$ per year [5]. The current situation in the Baltic States, which is related to heat energy consumption, is significantly worse. It is shown that in Latvia and Lithuania it exceeds $200 \mathrm{kWh} / \mathrm{m}^{2}$ per year [5]. Most residential buildings were built before the adoption of the existing building codes, so based on the reports of energy audit data collection [6], it can be concluded that in fact the heat consumption of households exceeds the permissible level of building standards. According to these reports, it averages at least $150 \mathrm{kWh} / \mathrm{m}^{2}$ per year. For future calculations, we use these data as the total heat consumption of households, which also includes the energy required for hot water preparation.

According to statistical data, the average household size in rural areas of Latvia, where firewood is mostly used for heating, is $93.9 \mathrm{~m}^{2}$ [4]. It is taken into account that this value is the average size of households, which also includes buildings without district heating, the area of which is below average. For further calculations, in this study the minimum heating area is taken to be $200 \mathrm{~m}^{2}$, as this area is recommended in the technical documentation of the boiler manufacturer [4]. According to previously accepted data on household size and average heat energy consumption, it is determined that a household with a heated area of $200 \mathrm{~m}^{2}$ consumes 39 MWh of heat energy during a calendar year.

In order to ensure a zero balance with the help of PV and mCHP technologies, their seasonal activities are taken into account, the activity of mCHP is directly related to climatic conditions, or heating season. Fig. 3 shows the typical heat energy demand during a calendar year. 
According to the regulations of the Cabinet of Ministers, the heating season in Latvia begins when the daily average air temperature is below $+8^{\circ} \mathrm{C}$ for three consecutive days [7], [8]. Evaluating the data of the Latvian Environmental Geology and Meteorology Center [9], it appears that the Latvian heating season begins in the second half of September and ends at the end of April, as well as the amount of precipitation, which increases heat loss.

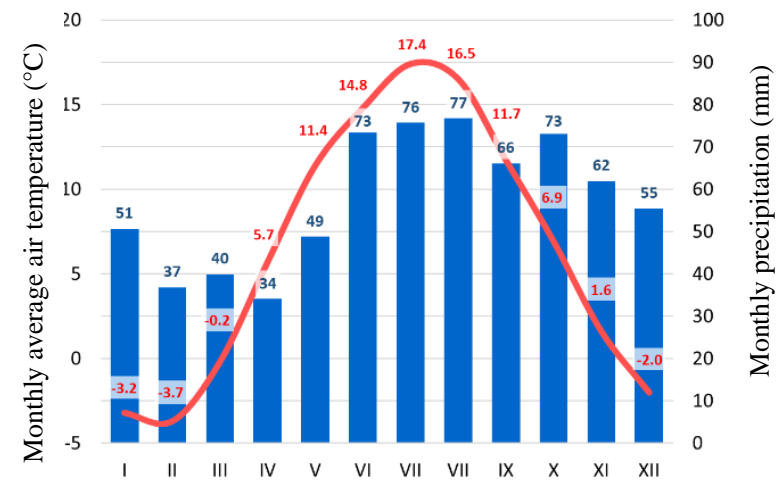

Fig. 3. Avarage temperature and moisture precipitation monthly [9].

\section{Households Electrical Loads}

Households vary in both area and annual electricity consumption [8]. A study [10] found that the average household in Latvia consumes $293 \mathrm{kWh}$ of electricity per month, which is in line with the Latvian Bureau of Statistics [5], that the largest share of $36.3 \%$ of households' annual electricity consumption is over $2000 \mathrm{kWh}$ per year, leading to further calculations. that the monthly electricity consumption of Latvian households is $293 \mathrm{kWh}$.

\section{Solar PV Panel Productivity}

The efficiency of solar PV panels is directly related to solar radiation entering the ground. The intensity of solar radiation in Latvia can be seen in Fig. 4.

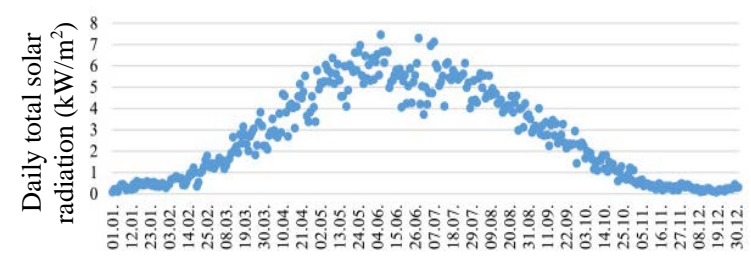

Fig. 4. Solar radiation in Latvia [9].

The amount of electricity obtained from solar PV panels, calculated on the area of the installed panels, depends on both their efficiency and installation features. Reviews [10], [11], [12] show that under optimal installation conditions, a $1 \mathrm{~kW}$ installed PV solar panel system produces about $800 \mathrm{kWh}$ of electricity annual.

\section{E. System Connection}

The study is performed on a system connected to an external Public electricity grid, Fig. 5.

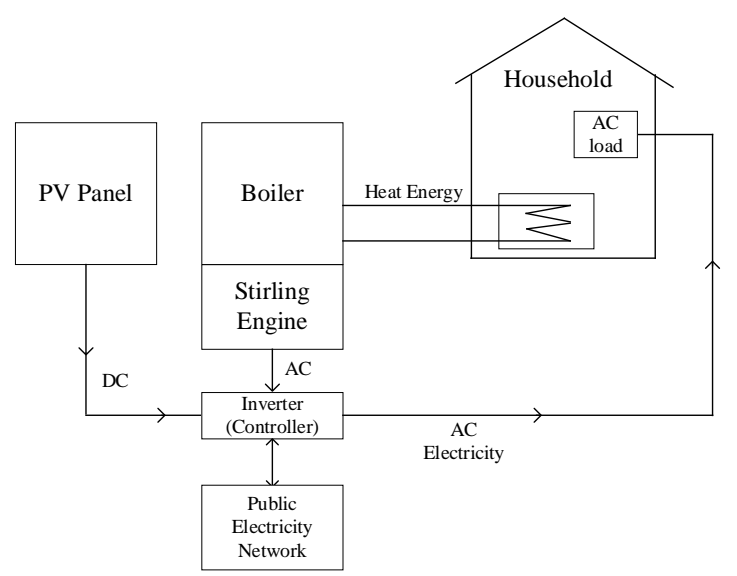

Fig. 5. System connection diagram.

The system is controlled by a control unit with a current inverter, which regulates the flow of electricity when transmitting or receiving it from the grid.

Heat energy is produced only for own consumption and is not connected to external grids.

\section{METHODS}

\section{A. Electrical and Thermal Energy Production}

Operation of the equipment used in the experiment.

\section{Thermal and elecrical energy produced by $\mathrm{mCHP}$}

Based on monthly changes in average air temperature [9], the intensity of heating equipment use is changing during the year. The electricity generation of the mCHP plant used in the study is directly related to the thermal energy production of the boiler. Electricity generation as a function of mCHP Stirling engine head temperature is shown in Fig. 6.

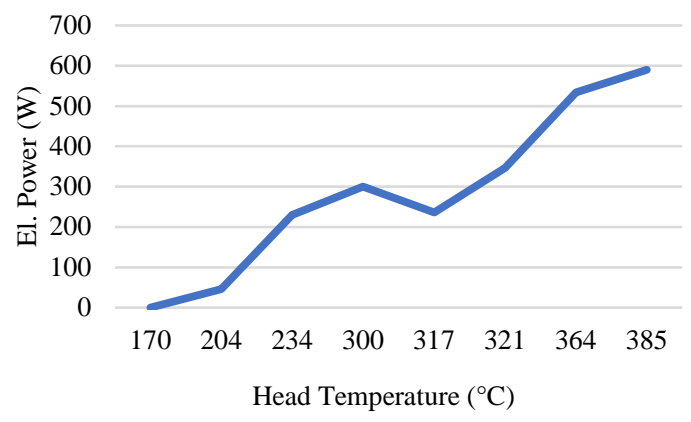

Fig. 6. Power generation capacity depending on Stirling engine head temperature .

In the course of the study, 9 experiments were performed, the aim of which was to find out how much heat and electricity the mCHP unit is able to produce in cogeneration mode. 
Environment. Technology. Resources. Rezekne, Latvia Proceedings of the $13^{\text {th }}$ International Scientific and Practical Conference. Volume 1, 132-138

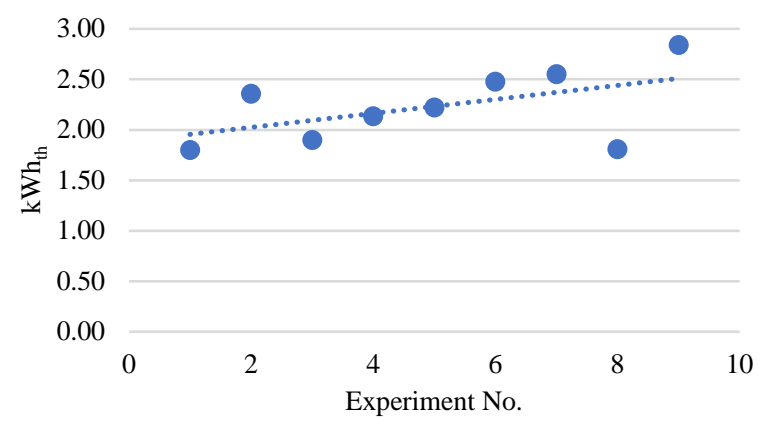

Fig. 7. Produced thermal energy from $1 \mathrm{~kg}$ of wood.

Experiment series ware done to determinate mCHP system electricity production (Fig. 8), and thermal energy (Fig. 7) from burning $1 \mathrm{~kg}$ of wood, first 3 experiments was done running experimental unit in thermal mode, 4-9 experiments in cogeneration mode.

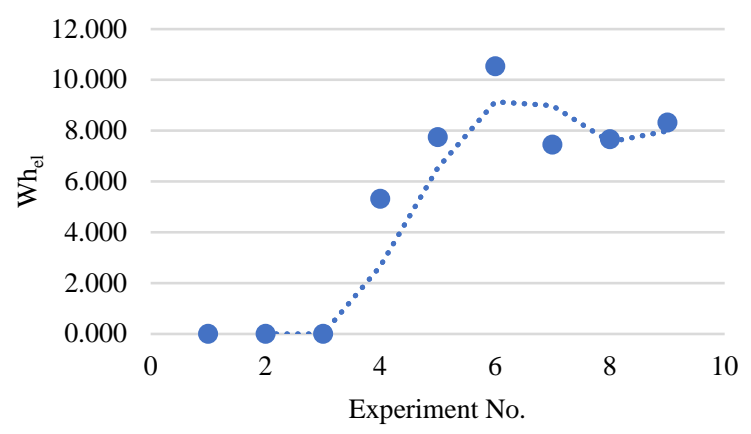

Fig 8. Produced electrical energy from $1 \mathrm{~kg}$ of wood.

\section{Electricity Produced from PV Panel System}

To determine the actual amount of electricity produced by PV panels, data was collected from the experimentally installed 1.2 kW solar panel system Table 2. Given that the experimental PV system was installed off-grid, it does not count the electricity produced without consumption, or if the battery system is fully charged. Based on the above, data on other solar panel systems installed in Latvia and Northern Europe, which are connected to the grid and all electricity generated is accounted for and transferred to the grid, ware analyzed. Data from grid tied systems were used for further calculations [13].

According to the experimental results in Fig. 8, we calculate that when the plant is operating in cogeneration mode, $1014 \mathrm{kWh}$ of electricity would be produced per year.

\section{B. Measurement methods and accuracy}

Analytical equipment was used: Heat energy counter Sontex supercal 739, providing +/-3\% accuracy.

VEXON $140 D$ meter used for accounting for electricity transferred to the public network, providing $+/-1 \%$ accuracy.

Stirling Engine el. generator instantaneous power and produced el. energy to network data collection was done with Stirling engine Data Viewer software and build in thermal sensors with precision of $+/-1 \%$.
Calibrated $200 \mathrm{~kg}$ mechanical weights with an accuracy of $+/-3 \%$ have been used to determine the weight of the loaded fuel.

The fuel temperature has been accepted identical to the room temperature as the fuel has long been located in the same room as the heating plant, a digital thermometer, Sonex, an accuracy of +/-2 \% was used for measurement. The humidity of wood was measured with the portable humidity meter iCcraft, checking each wood log, accuracy $+/-5 \%$.

Flow/return temperature fixated with boiler in build in temp sensors an accuracy of $+/-2 \%$.

Flue gas temperature read from the boiler's built-in sensors, accuracy $+/-3 \%$.

Flue-gas composition measured by calibrated analyser Testo 340, margin of error $0.2 \%$ by volume.

To minimize impact of analytical equipment inaccuracy to data offset, during each experiment measurements ware performed each $15 \mathrm{~min}$. In average 15 measurements ware performed per experiment, so we conclude that data accuracy is less than equipment max. inaccuracy range.

\section{V.RESULTS}

\section{A. Household Energy demand}

In section III we calculated household average annual heat and electrical demand. In this section we try to model how to cover those loads to reach zero NET balance of electrical and thermal energy demand. Primary calculation shows (section III) annual head energy demand is about 39 MWh and 3,516 MWh of electricity annual

\section{B. Produced Electricity From $\mathrm{mCHP}$}

As pointed out in the chapter (IV A, 1.), the electricity generation of the mCHP system directly depends on the heat energy of the boiler, as result total annual electricity produced with mCHP system is tightly depending on household heat energy demand. During the recalculation, it was determined that on average $0.026 \mathrm{kWh}$ electricity (Fig. 8) and $2.53 \mathrm{kWhth}$ (thermal energy) (Fig. 7) was obtained from burning $1 \mathrm{~kg}$ of wood. According to Chapter III (A), a household with these parameters consumes $39 \mathrm{MWh}$ of thermal energy annual. Correspondingly recalculating the capacity of the mCHP unit to produce electricity from the mentioned annual heat energy demand, we obtain that 1,014 MWh of electricity would be produced.

\section{Produced Electricity From PV Panels}

As it was mentioned on section III (C) from $1 \mathrm{~kW}$ of installed solar panels annual production is around $800 \mathrm{kWh}$. Our experiment installation is $1.2 \mathrm{~kW}$, so it could produce $960 \mathrm{kWh}$ electricity annual.

\section{Annual Electricity Demands Coverage}

As it was described on section III (C) monthly electricity demand on average household is $293 \mathrm{kWh}$, $3516 \mathrm{kWh}$ annual.

From mCHP annual electricity production would be1014 kWh, section (B). 
To cover annual electricity demand increase of PV panels installed power, compare to experimental installation, is necessary. To cover total demand of $3516 \mathrm{kWh}$, of what $1014 \mathrm{kWh}$ could be covered by mCHP system, $2412 \mathrm{kWh}$ is necessary to cover by installed PV panels. As it was described before, $1 \mathrm{~kW}$ of installed PV panels can produce in average 800 kWh electricity annual. To cover annual electricity demand of the household, 3015 $\mathrm{W}$ of installed PV power is necessary, it means 10 solar panels of $300 \mathrm{~W}$ each as mentioned on Table 2.

\section{E. Electricity NET Balance Calculation}

NET settlement system in Latvia is specified in the regulations of the Cabinet of Ministers [14]. Smooth grid balancing is this study objective

\section{F. Public Grid Disbalace}

Scientific paper [15] and public reviews [16], [17] identify the problem that NET Zero solutions based on PV panel systems only makes overload risks to public electricity grid due to seasonal its productivity. Current policy for NET settlements in Latvia is based solely on PV systems that are highly seasonal in the region. In this paper research was done how combination of mCHP and PV panels system decrease risk of seasonal public grid overload.

\section{G. NET Zero Calculation Scenarios}

Experimental based calculations ware done to define household annual electricity supply of consumption (SOC) by using combination of PV systems with mCHP to reach NET Zero balance. Results of those calculations are shown in Fig. 9.

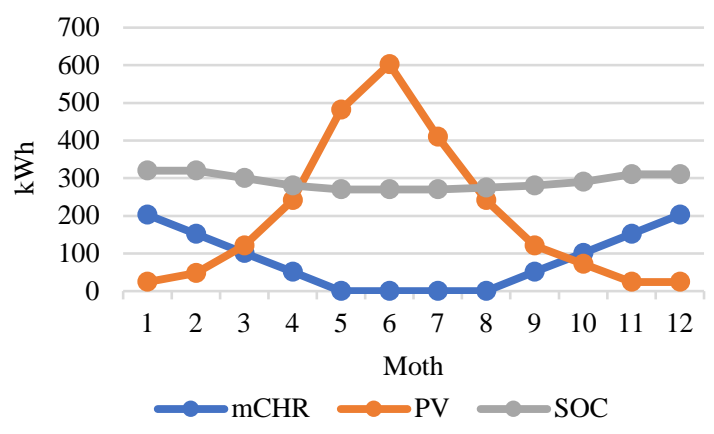

Fig. 9. Annual produced electricity with mCHP and PV systems for household Supply of Consuption (SOC).

As alternative scenario ware calculated to cover (SOC) by using PV panels system only to reach NET Zero balance.

In order to determine how much electricity a PV panel system is able to produce during a calendar year, an inventory was made from the experimental equipment Fig. 1 , as well as a review of the literature on the operation of similar PV systems in Latvia [10].

Comparison of those two alternatives, NET balance providing the household electricity supply with PV panels only (Scenario 2) and combination of PV + mCHP (Scenario 1), is shown in Fig. 10.

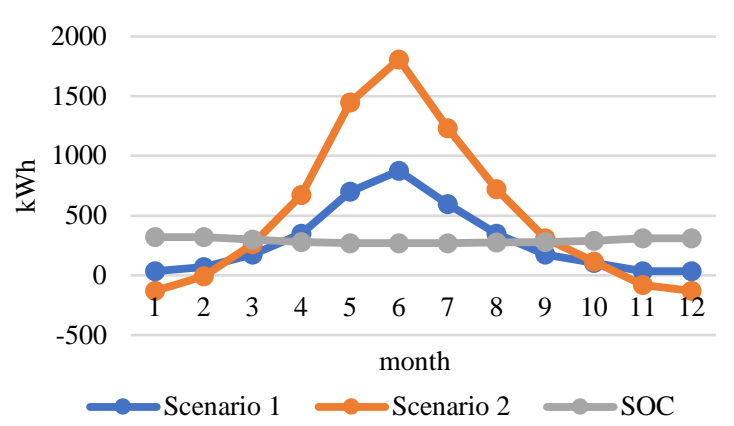

Fig 10. NET Zero energy balance with public grid.

\section{CONCLUSIONS}

In this paper, the first experimental results from the joint operation of a novel mCHP installations are presented. The system is composed by an External Combustion Microgen Stirling Engine micro-CHP unit and PV panels. All the energetic needs - both thermal and electrical - in a household are tried to achieve via experiments, using experiment data to interpolate it to annual heat and electricity demand. Reverse interpolation was done to set up minimum PV panels installed power to achieve annual NET Zero energy balance. This objective is subject to the generation capacity and the synchronization between the energy production and consumption profiles.

Synchronization process is depending on mCHP and household heat energy demand. As the test results shows mCHP can produce only about $1 / 4$ of the total annual electricity demand and fully supply with heat energy demand. From the Figure 8, we can conclude that during heating season it still need to receive electricity from grid, as result we have to install much more solar panels installed capacity as we thought before. It was far not enough with $1.2 \mathrm{~kW}$ of installed PV panels. Calculations show about $3 \mathrm{~kW}$ of installed PV panels capacity should be installed to reach zero NET balance.

Optimum calculation software method was used to find NET balance between household heat energy supply, electricity production from $\mathrm{mCHP}+\mathrm{PV}$ (scenario 1) and PV panels only with heat from conventional biomass boiler. Results of the NET balance calculations are present on Fig. 10. On the graph we can clearly detect positive result to minimize public grid disbalance over the year using Scenario 2. Public grid peak load was minimized by almost $40 \%$, compare to system with electricity production with PV panels only, (scenario 2). It was detected, that more less grid disbalance would be possible if also during summer period mCHP would be used, for example, for hot water preparation. We conclude also that by installing heat energy storage tank lower Public grid disbalance could be reached, but for detailed results additional research is necessary.

As the secondary objective was to achieve full $\mathrm{CO}_{2}$ neutrality of the household heat and electricity demand. 
Environment. Technology. Resources. Rezekne, Latvia Proceedings of the $13^{\text {th }}$ International Scientific and Practical Conference. Volume 1, 132-138

Carbon footprint calculation method was used to determinate household carbon neutrality.

Calculations shows, that by using wood for space heating household is carbon neutral in this aspect.

Electricity production from biomass mCHP and PV panels itself is carbon neutral. Using electricity from public grid is option to choose carbon neutral electricity, but this is actually more virtual aspect than practical, while with that choice is possible to support electricity production from renewable resources, but still most part of power is produced from fossil fuel.

Our calculation shows that use of PV and mCHP systems combination for household energy supply $\mathrm{CO}_{2}$ neutrality could be reached.

\section{ACNOWLEGEMENTS}

References Authors would like to thank RTU VASSI laboratory for the opportunity to use measuring equipment for the practical part of the research. Special thanks to Balteneco LTD for the opportunity to conduct research in its own boiler house, using its infrastructure. Thanks to "Radošo tehnologiju centrs" LTD for assistance by using its PV panel system for test purposes.

Thanks to Microgen LTD for the opportunity to use a micro-cogeneration unit for research and Dainis Seržants for responsiveness and quality work by connecting the research unit to the boiler house infrastructure

\section{REFERENCES}

[1] Central Statistical Bureau, "Environment and Energy, Energy Household Energy Consumption" [Online]. Available: http://data1.csb.gov.lv/pxweb/en/vide/vide_energetika_energ_p at/ [Accessed: Mar. 08, 2021].

[2] R. Padinger, et al, Best practise report on decentralized biomass fired CHP plants and status of biomass fired small- and micro scale CHP technologies. IEA Bioenergy, 2019.

[3] MAGA, "Wood-gasifying boilers MA" [Online]. Available: https://magasro.sk/en/wood-and-brickets-boilers-d/woodgasifying-boiler [Accessed: Mar. 10, 2021].

[4] Microgen Engine, “Microgen's compact gas fired HeaterGenerator,” Techn. Paper. [Online]. Available: http://stirlingtech.com/wp-content/uploads/2018/05/ThermoGen1.0kW.pdf [Accessed: May 15, 2018].
[5] Central Statistik Bureau Databases, "Overall description of dwellings (\%)” $\quad$ [Online]. http://data.csb.gov.lv/pxweb/en/sociala/sociala majapst/MTG02 0.px/ [Accessed: Mar. 15, 2021].

[6] D. Kostova, et al, "D2.2 Report on EPC best practices," QualDelEPC, Goteborg, Sweden, Rep., 2020.

[7] Cabinet of Ministers Republic of Latvia, "Cabinet Regulation No. 280. Regulations Regarding the Latvian Construction Standard LBN 002-19, Thermotechnics of Building Envelopes,” Latvijas Vēstnesis, vol. 135, 2019.

[8] Cabinet of Ministers Republic of Latvia, "regulation No. 204. On the conditions of heat supply," Latvijas Vēstnesis, vol. 125, 1994. (in Latvian)

[9] LVGMC, "Latvian climate" [Online]. Available: https://videscentrs.lvgmc.lv/lapas/latvijas-klimats [Accessed: Mar. 15, 2021]. (in Latvian)

[10] L. Rozentale, D. Lauka, D. Blumberga, “Accelerating power generation with solar panels. Case in Latvia,” Energy Procedia, vol. 147, pp. 600-606. https://doi.org/10.1016/j.egypro.2018.07.077

[11] I. Pakere, D. Blumberga, "Solar power or solar heat: What will upraise the efficiency of district heating? Multi-criteria analyses approach”, Energy, vol. 198, pp. 117291, May 2020.

[12] A. Simola, et al, "Optimal dimensioning of a solar PV plant with measured electrical load curves in Finland," Solar Energy, vol. 170, pp. 113-123, Aug. 2018.

[13] J. Telicko, D. Heincis, A. Jakovics, "A study of solar panel efficiency in Latvian climate conditions," Proceedings of the 12th Nordic Symposium on Building Physics, vol. 172, pp. 16007, Jun. 2020.

[14] Cabinet of Ministers Republic of Latvia, "Facilitated conditions for net system users," April 2020 [Online]. Available: https://www.mk.gov.lv/lv/jaunums/atviegloti-nosacijumi-netosistemas-lietotajiem [Accessed: Mar. 14, 2021]. (in Latvian)

[15] K. N. Nwaigwe, P. Mutabilwa, E. Dintwa, "An overview of solar power (PV systems) integration into electricity grids,” Materials Science for Energy Technologies, vol. 2, iss. 3, pp. 629-633, Dec. 2019.

[16] The Weekend Australian, A. Hepworth, "Rooftop solar panels overloading electricity grid,” October 2011 [Online]. Available: https://www.theaustralian.com.au/news/rooftop-solar-panelsoverloading-electricity-grid/newsstory/5ea583571dde0830ec34d3cd8c32b9dc [Accessed: Mar. 01, 2021].

[17] BUILD, "Rapid increase in solar installations potentially overloading the grid" [Online]. Available: https://build.com.au/rapid-increase-solar-installations-potentiallyoverloading-grid [Accessed: Mar. 14, 2021]. 